\title{
MEASUREMENT LEVELS OF THE SPATIAL INTEGRATION - SUGGESTIONS FOR A CENTRAL-EUROPEAN FACTOR GROUP
}

\author{
Andrea USZKAI ${ }^{\mathrm{a}}$ \\ ${ }^{a}$ Széchenyi István University Doctoral School of Regional- and Economic Sciences, Address: Egyetem \\ tér 1. Györ H-9026, e-mail: uszkai.andrea@sze.hu \\ Hungarian Academy of Sciences Centre for Economic and Regional Studies, Institute for Regional \\ Studies, Address: Papnövelde u. 22. Pécs H-7621, E-mail: auszkai@rkk.hu
}

Cite this article: Uszkai, A. (2015). Measurement Levels Of The Spatial Integration - Suggestions For A Central-European Factor Group. Deturope, 7, 2: 65-80

\begin{abstract}
The objective of the study is to point out, what kind of measurement methodologies and factor groups are used to determinate the depth of the spatial integration in the national and international scientific literature. Integration means in this sense the interconnection of several (spatial) units (Kulcsár-Rostás, 1989; Kovács, 2001; Kiss, 2005). One of the most widely interpreted types of the integration is the economic integration, which can be applied to enterprises and spatial units as well. This study focuses on the last one and examines it at three territorial levels, distinguishing global, supranational (among national states) and subnational levels. The possible measurement methods are significantly determined by the spatial levels. The paper makes some suggestions for the possible measurement method in CenrtralEuropean context.
\end{abstract}

Keywords: measurement, spatial integration, global, regional, cross-border, functional urban area

\section{INTRODUCTION - CONCEPTUAL FRAMEWORK}

Because of the complexity and importance of the concept of spatial integration, it is necessary to define the meaning of this phenomenon in the paper. The idea of integration (social, economic, political) underpins the formation of the European Union. Integration tends to be regarded as a positive response to the disintegration of traditional structures caused by the globalisation. Within the EU, several distinct concepts of integration can currently be identified. This paper applies the first version of the definition, summarised in the first official project of ESDP: "Spatial integration expresses the opportunities for and level of (economic, cultural) interaction within and between areas and may reflect the willingness to co-operate. It also indicates, for example, levels of connectivity between transport systems of different geographical scales. Spatial integration is positively influenced by the presence of efficient administrative bodies, physical and functional complementarity between areas and the absence of cultural and political controversies." (Boe, Grasland, Healy et.al., 1999:7).

\section{The measurement of the integration at global and supra-national level}

Regional integration is a worldwide phenomenon of territorial systems that increase the 
interactions between their components and create new forms of organisation, co-existing with traditional forms of state-led organization. The processes of regional integration that emerged after WW II, were originally mostly about trade and economics, but it has become clear that, especially since the $1980 \mathrm{~s}$, with the so-called 'new regionalism' wave, regional integration can be seen as a multidimensional process that implies, next to economic cooperation, also dimensions of politics, diplomacy, security, culture, etc. (Lombaerde - Langenhove, 2005)

At global level, the globalization index was introduced by the KOF Swiss Economic Institute to measure the integration processes at global level in 2002. This index investigates the integration in three dimensions (economic, social and political) with distinct weights. In the globalization index of 2014 included 36\% economic, 38\% social and $26 \%$ political dimension. In KOF index 2014, 207 were analysed and Hungary is ranked at the $9^{\text {th }}$ place. (KOF Swiss Economic Institute, 2014)

Moreover, the so called "System of Indicators of Regional Integration (SIRI)" provides another opportunity to measure the global integration, which can monitorize the regional integration processes at global scale, involving the most relevant key variables. There is evidence of a growing interest of policy-makers for such a system (Lombaerde - Langenhove, 2005) (Tab. 1).

Table 1 Proposal for classifying variables in the System of Indicators of Regional Integration (SIRI)

\begin{tabular}{|c|l|}
\hline \multicolumn{1}{|c|}{ Categories } & \multicolumn{1}{c|}{ Sub-categories } \\
\hline I. Actors & $\begin{array}{l}\text { Number of integration units involved (countries, regions, } \\
\text { organisations, ..) } \\
\text { Number and quality of actors in the decision-making } \\
\text { process } \\
\text { Level of activity of the actors } \\
\text { Actors'opinions and perceptions (survey results) } \\
\text { Overlapping memberships }\end{array}$ \\
\hline II. Structural factors & $\begin{array}{l}\text { Proximity of the actors (geographical, cultural, etc.) } \\
\text { Structural complementarities } \\
\text { Structural asymmetries } \\
\text { Historical patterns of cooperation, integration and } \\
\text { conflict }\end{array}$ \\
\hline III. Institutionalisation & $\begin{array}{l}\text { Number of treaties and agreements } \\
\text { Contents of treaties and agreements } \\
\text { Time frames of treaties and agreements } \\
\text { Institution building } \\
\text { Arrangements on common policies and policy } \\
\text { coordination } \\
\text { Gradualism, exemptions and differential treatments }\end{array}$ \\
\hline IV. Implementation & $\begin{array}{l}\text { Status of implementation of general treaties } \\
\text { Status of implementation of specific agreements } \\
\text { Degree of accomplishment of convergence criteria }\end{array}$ \\
\hline
\end{tabular}


Table 1 (continued)

\begin{tabular}{|c|l|}
\hline IV. Implementation & $\begin{array}{l}\text { Status of implementation of general treaties } \\
\text { Status of implementation of specific agreements } \\
\text { Degree of accomplishment of convergence criteria }\end{array}$ \\
\hline V. Effects & $\begin{array}{l}\text { Human development } \\
\text { Economic growth } \\
\text { Trade } \\
\text { Migration } \\
\text { Capital flows }\end{array}$ \\
\hline VI. Interdependence & $\begin{array}{l}\text { Mobility of persons } \\
\text { Political interdependence (existence of common policy } \\
\text { variables, de facto coordination of policies, occurrence } \\
\text { of conflicts, tensions, ...) } \\
\text { Economic interdependence (trade, capital flows, } \\
\text { correlation of activity levels, symmetry of shocks, ...) } \\
\text { Information and knowledge flows }\end{array}$ \\
\hline Informats
\end{tabular}

Source: Lombaerde - Langenhove, 2005:21.

Pratically, the application of this method is rather difficult, because of the complexity of measurement of special variables, availability of reliable data and the financing of the measurement system. A crucial issue can be the translation of the chosen variables into indicators (Lombaerde - Langenhove, 2005).

Moving on the next level of the spatial integration, let's take a look at the supranational integration. The process of economic and political integration in Europe began shortly after the World War II, and was intended to support the economic development of all participating countries. European integration did not happen overnight, but has been an ongoing piecewise transition process. Two major components of European integration are the free movement of goods and services, as well as labour (Bartz - Fuchs-Schündeln, 2012). Many of empirical evidence reveals the ongoing long-term parallel trends of increasing regional integration and globalisation. The EU is a part of this phenomenon: on the one hand, within-EU integration has become more important over the last decades and, on the other hand, the EU as a whole has gained greater exposure to the world economy (Commendatore et.al 2014). So, the supranational integration means the integration process between (in this case: European) countries. At this level, König (2014) summarises the content of the "European Integration Index". Due to limited data availability for the Central and Eastern European (CEE) countries (especially until 2004), the EU Index only covers those member states that entered the EU no later than 1995 (the EU-15). Since Luxembourg contains many extreme values, it is not considered in the index. In these 14 remaining member states, 25 different indicators (in 4 categories: EU single market (for goods, services, capital and labour); EU homogeneity (degree of economic convergence); EU symmetry (of business cycles); and EU conformity 
(institutional participation and compliance with the acquis communautaire) over the period 1999 - 2010 are investigated. Belgium shows the highest level of European integration in 2010, whereas Greece is at the very bottom of the ranking (König, 2014).

Another measurement belongs to the United Nations University Comparative Regional Integration Studies (UNU- CRIS), which analyzes the integration processes of the ASEAN, NAFTA, Integrated Asia (IA16), East Asia Summit, Mercosur, and the EU 15 in the point of economic, political and cultural view (Palánkai, 2010). Kocziszky (2000) pointed out that the supranational integration can not be expressed with only one index, therefore he has separated it into four distinct dimensions: integration of the inland markets, protection of the inland markets, integration of the institutional system and integration of the economic policies (Kocziszky, 2000). Moreover, at this level can be measured the maturity of integration in the case of countries, which can be associated with Palánkai (analysis of Central-and Eastern European countries in 2004) and Endrődi-Kovács (analysis of Croatia in 2010 and Serbia in 2012). It is important to mention that this kind of measurement is not equal to the accession criteria.The detailed description of the results does not belong to the subject of this paper.

\section{Measurement of the integration at sub-national level, with special regard to the cross-}

\section{border functional urban areas}

Around $80 \%$ of the European population lives in urban areas and cross-border urban areas represent a large part of this category (URBACT, 2014). The importance of cross-border urban areas has increased in the last decades among policy makers and researchers as well. In the scientific literature, there are two main definitions for the functional urban areas.

First of all, the OECD with the EU has developed a harmonised definition of urban areas "as functional economic units, consisting of highly densely populated municipalities (urban cores) as well as any adjacent municipalities with high degree of economic integration with the urban cores, measured by travel-to-work flows." (OECD, 2013:155) This definition overcomes previous limitations for international comparability linked to administrative boundaries. The definition is applied to 29 OECD countries. It identifies 1179 urban areas of different size. The functional urban areas with more than 500000 population are defined as metropolitan areas (OECD, 2013). According to the OECD "each functional urban area is an economic unit characterised by densely inhabited "urban cores" and "hinterlands" whose labour market is highly integrated with the cores." (OECD, 2012:1) In the classification of the OECD the functional urban areas do not cross the border; they are located within the country in all of cases. 
The other meaning of the functional urban areas was identified by the ESPON Metroborder project (2010). Metroborder stands for cross-border polycentric metropolitan regions. It is a European multi-annual research project and funded by the European Spatial Planning Observation Network (ESPON). The objective of the ESPON Metroborder project is to determine the added value of an organised metropolitan region in comparison to a "laissez faire" approach and to identify what are the main obstacles of governance in the Greater Region and the Upper Rhine Region. (Metrolux, 2013) The Final Report of this project (2010) defines the concept of cross-border polycentric metropolitan regions (CBPMR) "as political constructions based on cross-border agreements which consider the existence of national borders as a resource for increasing interactions at the local level and based on the embeddedness of the metropolitan centre(s) in global networks. Because CBPMRs are composed of several urban centres located on either side of a border, these regional political initiatives can mobilise different geographical scales in order to utilise the assets and complementarities of the morphological and functional polycentricity" (ESPON, 2010). Each CBPMR has a cross-border core area, which are defined on the scale of „Functional Urban Areas" (FUAs), and thus on a local scale. "Functional urban areas are defined primarily by commuter flow data at the local level. The precise delimitation of the FUA is associated with the threshold of $10 \%$ of the occupied of the active population commuting to the central Morphological Urban Area (MUA). These MUAs are defined as densely built and inhabited urban areas." (ESPON, 2010)

One of the first attempts to measure the sub-national integration took place in 1999 with a workgroup of Belgium, France, Portugal and United Kingdom. Their investigation, which was related to the Western-European core areas of the EU, has analyzed the spatial integration from three different aspects: spatial interactions, spatial patterns and spatial co-operation. The main aspects and their associated indicators are summarised in Table 3. (Boe, D. - C. Grasland - Healy, A. et.a.,1999) (Tab. 2).

Table 2 Main aspects and potential indicators to measure the spatial integration in crossborder regions

\begin{tabular}{|l|l|}
\hline \multicolumn{1}{|c|}{ Main aspects } & \multicolumn{1}{|c|}{ Potential indicators } \\
\hline $\begin{array}{l}\text { Spatial interaction measured through flows and } \\
\text { barriers }\end{array}$ & $\begin{array}{l}\text { goods transport flows, inter-regional migration flows, } \\
\text { barriers to trade flows, flows of goods, residential } \\
\text { migration flows }\end{array}$ \\
\hline $\begin{array}{l}\text { Spatial patterns: homogeneity, discontinuities } \\
\text { and multiscalar position }\end{array}$ & $\begin{array}{l}\text { wealth differential between neighbouring regions, } \\
\text { multiscalar profile and dynamics of regions (based on } \\
\text { GNP per capita) }\end{array}$ \\
\hline Spatial co-operation & $\begin{array}{l}\text { national financing of the Interreg II A programmes, } \\
\text { town and city twinning activities }\end{array}$ \\
\hline
\end{tabular}

Source: Boe, D. - Grasland , C- Healy, A. et.a., 1999 
Taking into consideration the aspects above, spatial integration in cross-border regions was determined by the difference of density, transport network, urban network, flows, territorial homogeneity, and administrative and policy grid. Figure 1 summarises the main features of integrated versus not-integrated cross-border regions and the integration dynamics.

Figure 1 Selected fields for a systemic approach of spatial integration in cross-border regions

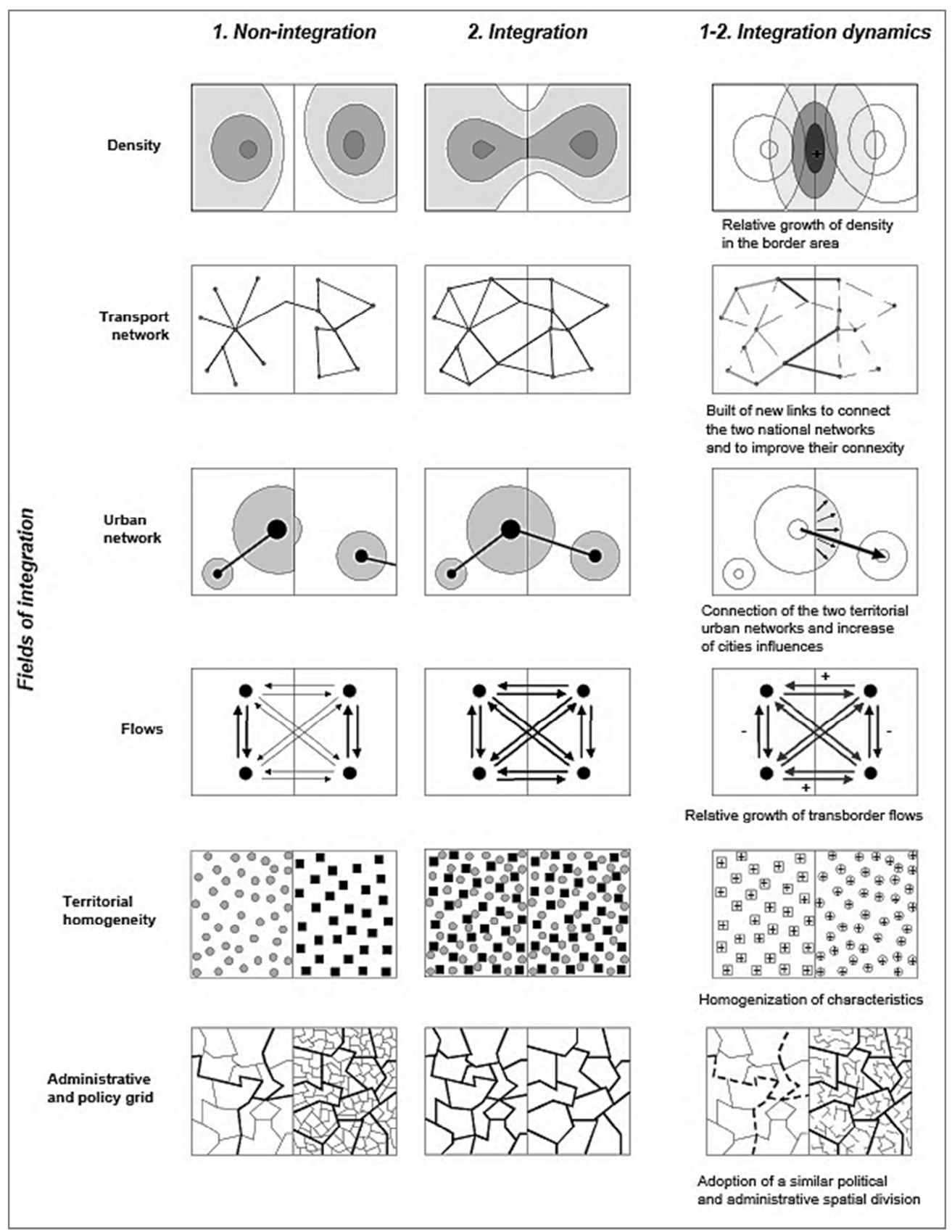

Source: Boe, D. - Grasland, C. - Healy, A. et.a.,1999

Another approach can be read in the Report 2010 of the ESPON-Metroborder project. The cross-border integration was examined through the interaction and convergence in economic, transportation, population, political and urbanisation dimensions (Tab. 3). 
Table 3 Indicators of cross-border integration in the ESPON-Metroborder project (2009-2010)

\begin{tabular}{|l|l|l|}
\hline Domain & \multicolumn{1}{|c|}{ Interaction } & \multicolumn{1}{c|}{ Convergence } \\
\hline Economy & Cross-border commuting & $\begin{array}{l}\text { Gross domestic product (GDP) per capita } \\
\text { Labour force }\end{array}$ \\
\hline Transportation & Cross-border lines of transportation & - \\
\hline Population & - & $\begin{array}{l}\text { Population density } \\
\text { Residents' citizenship }\end{array}$ \\
\hline Policy & Structures of cross-border cooperation & - \\
\hline Urbanisation & Functional urban areas & Morphological urban areas \\
\hline
\end{tabular}

Source: Metrolux, 2013.

The project mentioned above included the following cross-border functional urban areas: Aachen-Liege-Maastricht, Basel, Geneva, Lille, Luxembourg, Nice-Monaco-San Remo, Copenhagen-Malmo, Saarbrucken, Strasbourg, Vienna-Bratislava and Katowice-Ostrava. (Fig. 2).

Figure 2 Cross-border functional urban areas in ESPON-Metroborder project

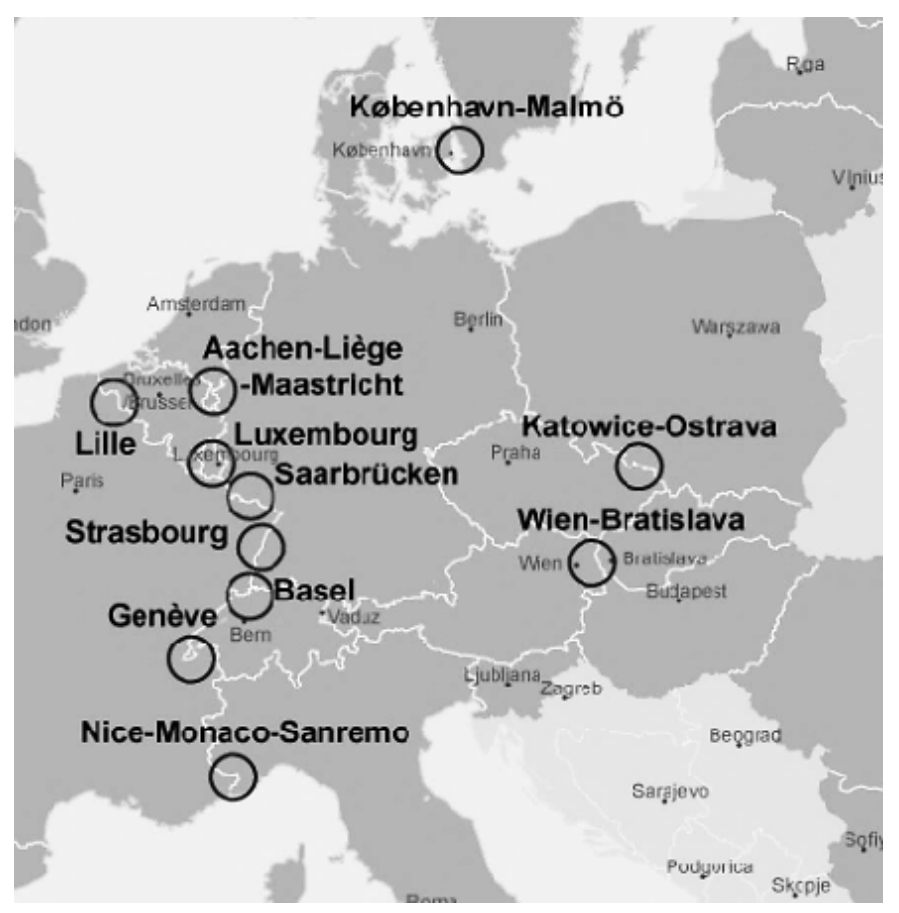

Source: ESPON, 2010

Decoville - Durand, et.al. (2010) have also examined the process of the spatial integration in demographic, labour market and economic dimensions, from the aspects of economic interactions, economic disparity, territorial homogeneity and cultural differences, based on the above mentioned functional urban areas, except Ostrava-Katowice, which was not involved to this analyzis. Table 4 summarizeses the main results of this investigation 
Table 4 Results of the analysis of Decoville

\begin{tabular}{|l|c|c|c|c|}
\hline \multirow{2}{*}{$\begin{array}{l}\text { Cross- } \\
\text { border metropolitan } \\
\text { regions }\end{array}$} & $\begin{array}{c}\text { Economic } \\
\text { interactions }\end{array}$ & $\begin{array}{c}\text { Economic } \\
\text { disparity }\end{array}$ & $\begin{array}{c}\text { Territorial } \\
\text { homogeneity }\end{array}$ & $\begin{array}{c}\text { Cultural } \\
\text { differences }\end{array}$ \\
\cline { 2 - 5 } & $\begin{array}{c}\text { Cross- } \\
\text { border commuters }\end{array}$ & $\begin{array}{c}\text { Differentials of } \\
\text { GDP per capita }\end{array}$ & $\begin{array}{c}\text { Residents' } \\
\text { citizenship }\end{array}$ & Language barrier \\
\hline $\begin{array}{l}\text { Aachen-Liege- } \\
\text { Maastricht }\end{array}$ & 2 & 2 & 5 & Yes \\
\hline Basel & 4 & 5 & 3 & Partial \\
\hline Geneva & 4 & 4 & 4 & No \\
\hline Lille & 3 & 1 & 5 & No \\
\hline Luxembourg & 5 & 5 & 3 & Partial \\
\hline $\begin{array}{l}\text { Nice-Monaco-San } \\
\text { Remo }\end{array}$ & 3 & 4 & 2 & Partial \\
\hline Copenhagen-Malmo & 2 & 2 & 2 & Yes \\
\hline Saarbrucken & 3 & 1 & 1 & Yes \\
\hline Strasbourg & 1 & 3 & 1 & Yes \\
\hline Vienna-Bratislava & 1 & 1 & 5 & \\
\hline
\end{tabular}

Note: $1=$ very weak, $2=$ weak, $3=$ moderate, $4=$ strong, $5=$ very strong.

Cross-border commuters: 5: > 60 000; 4: $40000-60$ 000; 3: $20000-40$ 000; 2: $10000-20000 ; 1:<10000$

GDP: 5: > $30000 € ; 4: 20000-30000 € ; 3: 10000-20000 € ; 2: 5000-10000 € ; 1:<5000 €$

Source: Decoville - Durand et.al ., 2010

Vienna-Bratislava functional urban area is the most important from the point of view of this paper among the above areas, because it represents the Central-and Eastern European region. According to the results of this examination, the economic interactions (measured by the number of the cross-border commuters) and territorial homogeneity (differentials of GDP per capita) are very weak, the economic disparities can be considered moderate, moreover cultural differences (language barriers) also appear. In summary, based on this indicator system this region belongs to the weakly integrated cross-border functional urban areas (Decoville - Durand, et.al. , 2010).

\section{Suggested factors for the measurement of integration in Central-European}

\section{(CENTROPE) region}

As we know, there are numberless approaches for the interpretation of the term "CentralEurope". On of these concepts is the so called "Centrope", which has been created in 2003, with the Declaration of Kittsee. This declaration was signed by governors and comitatus presidents of the above mentioned countries, provinces, regions and cities. (Schwiezer-Koch, 2013) and it is one of the most important formal frameworks of the cooperation in the Central-European region and it also functions today in several regions including Vienna and other Austrian provinces such as Lower Austria and Burgenland, the region of South-Moravia in the Czech Republic, the region of Bratislava and Trnava in Slovakia, Györ-Moson-Sopron 
and Vas counties in Hungary, and the cities of Eisenstadt, St. Pölten, Brno, Bratislava and Trnava (Centrope, 2015) (Figure 3.).

Figure 3 Centrope partner regions and cities

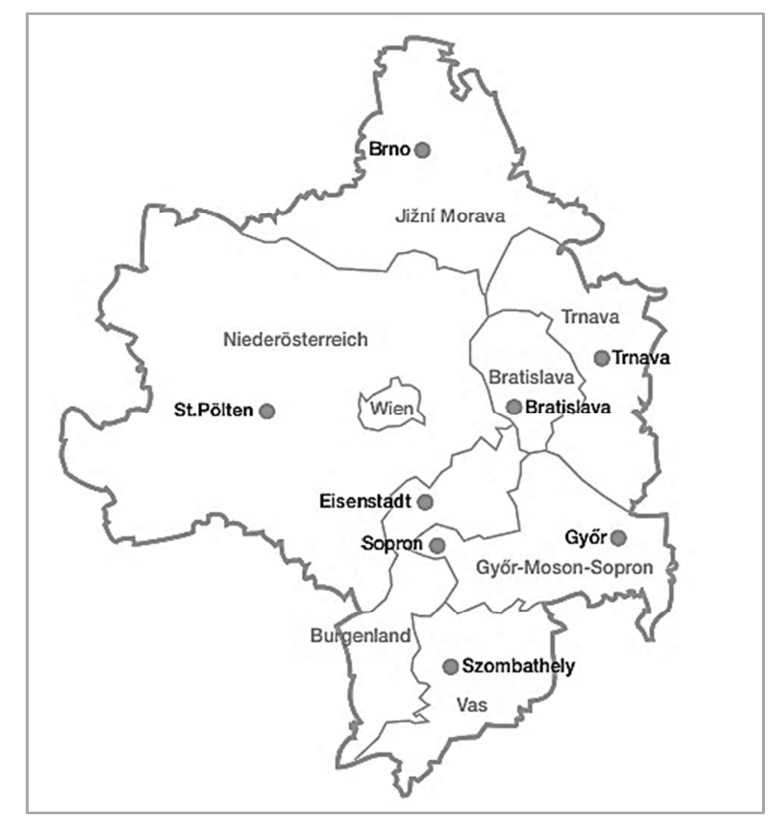

Source: Centrope, 2010

Today, Centrope may be called one of Europe's most dynamic and interesting economic areas: almost all partner regions are among the economic driving forces of their respective countries and boast above-average performance indicators. Roughly six and a half million people live in the eight federal provinces, regions and countries that make up the CentralEuropean region. The two capitals Bratislava and Vienna are situated at a distance of around 60 kilometres from each other, Brno and Györ as additional cities of supra-regional importance as well as numerous other towns are the driving forces of an economically and culturally expanding European region (Centrope, 2015).

Further part of this chapter suggests some factors, which can influence the integration processes in Centrope region.

First of all, we have to mention that the Central-and Eastern European countries have a long common history. At the dawn of the World War I. the Austrian-Hungarian monarchy comprised contemporary Austria, Hungary, Slovenia, Croatia, Bosnia-Herzegovina, the present-day Czech and Slovak Republic, Vojvodina, Transylvania, Trentino-Alto Adige and parts of contemporary Southern Poland and Western Ukraine. In contrast to the Western European countries, it was a multi-ethnic state formation, in which people of different ethnic descent (Germans, Hungarians, Czechs, Slovaks, Croats, Serbs, Bosnians, Romanians, Poles, 
Ruthenians, Slovenes and Italians) lived together (Jennissen, 2011). However, this empire split into a number of different countries in 1918 the empire, this coexistence determined the historical and economic development process of these states for a long time. Thus, the common historical background and roots can be considered as a potential integration factor.

The next influencing factor may be the cross-border commuting. This indicator was also applied in the former international scientific literature as well. Its relevance in the case of Centrope is unquestionable, because its intensity is very different across several borderlines of Centrope.

As for Austrian-Hungarian border, after 1989, the borders have opened and the crossings were more and more significant, especially the shopping tourism has flourished. The crossborder relationships have become stronger and diverse (employment, ownership, tourism, use of services etc.) After the EU accession of Austria (1995), the country turned westward and paid more attention to the Western integration, the economic and political importance of the Austrian-Hungarian border region has temporarily decreased (Rechnitzer,1999). Despite of this political phenomenon, the connections have become more intensively.

In the case of (Czech) Slovak-Hungarian borderline, cross-border employment and shopping were usual activities already during the socialism as well (Jagodič, 2010). The two states, Czechoslovakia and Hungary have signed an international convention about the bilateral employment in 1985. In this era, the commuting was dominant in both directions. Since 1999 the number of commuters from Slovakia to Hungary increased rapidly. In the western part of the border region on the Slovakian side the unemployment rate is higher than and on the Hungarian side, large industrial centres can be found near the border (GyörKomárom-Almásfüzitő, Esztergom-Dorog-axis, Tatabánya, etc.), which has been exhausted the local workforce capacity. Since 1999, the development of the commuting was supported by a Framework Agreement between the two countries and it imposed so loos conditions that practically the barriers have discontinued. Therefore, May 2004 was not a great change for the labour market. In 2005, the number of the Slovak citizens working in Hungary has been estimated at around 30 thousand people. Since the EU accession, a very strong economic development can be observed in Slovakia and of course, it has got effects on its labour market as well. Thus, the number of commuters is decreasing in the western border section too, probably; it will stabilize at a healthy level. However, it is recognized that the process started also in the opposite direction. (Hardi-Lampl, 2008)

As for the Austrian-Czech border, since 1990 the labour market relationships have taken place either in the form of cross border labour migration or cross-border commuting 
especially from the Czech regions to Austria. The typical sign of the regional labour market is one-way economic migration and commuting. Workers from the Czech Republic use the opportunity to find employment in nearby Austrian regions in branches like construction, tourism and social and private services, agriculture and forestry. Although the EU accession in May 2004 allowed the Czech citizens to enter the Western Europe labour market without working permission, Austria like one of most EU15 countries introduced transitional provisions to free movement of labour up to 7 years which affects the bilateral labour market (Operational Programme Objective European Territorial Co-operation Austria - Czech Republic 2007-2013).

In the case of Czech-Slovak border, according to research of Halás (2006), the intensity of cross-border relations is very different at the several parts of this borderland. It is especially high in the northern and southern parts of the borderland, but both sections are of a clearly different character. In the southern part, besides a good permeability of the state border makes it possible to expand the inter-settlement relations, moreover, the short transport distances support the creation of relations. For the inhabitants in the northern part of Slovak borderland Ostrava-Karviná region in the Czech Republic is very attractive. These centres are more remote from the state border in comparison with Hodonín or Břeclav in the south, but are much more numerous and larger. In the central section of the borderland, the intensity of the cross-border relations is very low, because the orientation of local communes mainly to the regional centres of the Central Považie region (Halás, 2006).

As we could see, the main charecteristics and intensity of cross-border commuting in Centrope are very distinct, thus a deeper analysis is necessary.

The next suggested factor is the ethnic composition of inhabitants. It shows the proportion of the population from neighboring countries. In an integrated border region this rate is obviously higher, than in a separated one, because this factor may represent the extent of the common land use. In the case of Centrope, it is also the tendency of the last years that a significant number of Slovak citizens settled down at Hungarian settlements near Bratislava. Their lifestyle primary connects to Slovakia, thus everyday cross-border travelling requirements occur in their case (Prileszky, 2010). Based on the data (March, 2010) of the Land Office of Győr-Moson-Sopron country, 1269 people living in Győr-Moson-Sopron have registered address in Slovak, 1256 of them purchased real estate since 1. May, 2004 in this country. The purchases were made mostly in 2008 and 2009, but the purchase of real estate wave has started in 2004. The resolution of the country office confirms that Rajka, Dunakiliti, 
Dunasziget, Feketeerdő settlements are the most attractive due to the proximity of the Slovak border and extending suburbanization of Bratislava (Baj, 2010).

In addition, it can be assumed that similar political and administrative systems and decision-making competencies may support the integration process of a cross-border region. In contrast, Centrope unites countries and regions whose political and administrative systems, while principally similar, do vary markedly in some respects, as federally organised administrations exist side by side with those that attach greater importance to the central government (Centrope, 2014).

The next factor in the Central-European integration model can be the existence of language barriers. The relevance of this indicator was also proved by the above presented research of Decoville - Durand, 2010. Language barriers appear in the case of Centrope, where four national languages meet.

The Centrope, as a polycentric region is not viable without rapid and well-established transport infrastructure, which allows a significant degree of economic integration, labour mobility and commuting. Since the 2003 foundation of the Centrope region always played an important role in the region's life the transport development issues. A significant growth of the traffic between the member regions of the Centrope countries may support the dynamic integration. The other factor, which contributed to successful integration, is the efficiency of more transnational transport corridor crosses. A greater traffic growth can be expected in the future between the four countries, which is also displayed in the Austrian cross-border traffic forecast. (Uszkai-Jóna, 2014) In the topic of physical accessibility, it is necessary to examine the continuity of the transport network across the border and explore its deficiencies.

Networks can appear in other context as well, such as inter-organizational relationships, including corporate, government and non-profit sector. The intensity of their cross-border relationships can be examined from the aspect of integration. If these cooperations are uncertain and short-term, it can negatively influence the integration of the given region. The exploration of clusters and networks within the Centrope can help to understand the operation of several inter-organizational relationships.

Another suggested factor is economic disparities (measured by GDP per capita), which was applied in former researches as well. Its relevance among the indicators is unquestionable. Before the financial and economic crisis, Centrope was one of the fastestgrowing areas of the EU in terms of GDP, although the individual performance of countries tended to differ significantly. While Slovakia and the Czech Republic had very high GDP growth attaining $7,7 \%$ and $5,9 \%$, respectively (measured as average growth in constant prices 
in 2004-2007), Austria's performance (3.1\%) was weaker if compared to the Centrope average $(5,0 \%)$. However, when compared to the EU-27 average of 2,7\%, Austria also performed above average. Hungary suffered in the pre-crisis period from a restrictive fiscal policy, and its growth rates amounting to 3,3\% were lower than in Slovakia and the Czech Republic, but higher than in Austria. Over a longer time horizon, the average growth performance in centrope tended to improve from 2004 onwards, with the exception of Hungary (Centrope, 2010).

Figure 4. summarizes the suggested factor group, which can influence (positively or negatively) the spatial integration process in Centrope region.

Figure 4 Possible factors influencing spatial integration

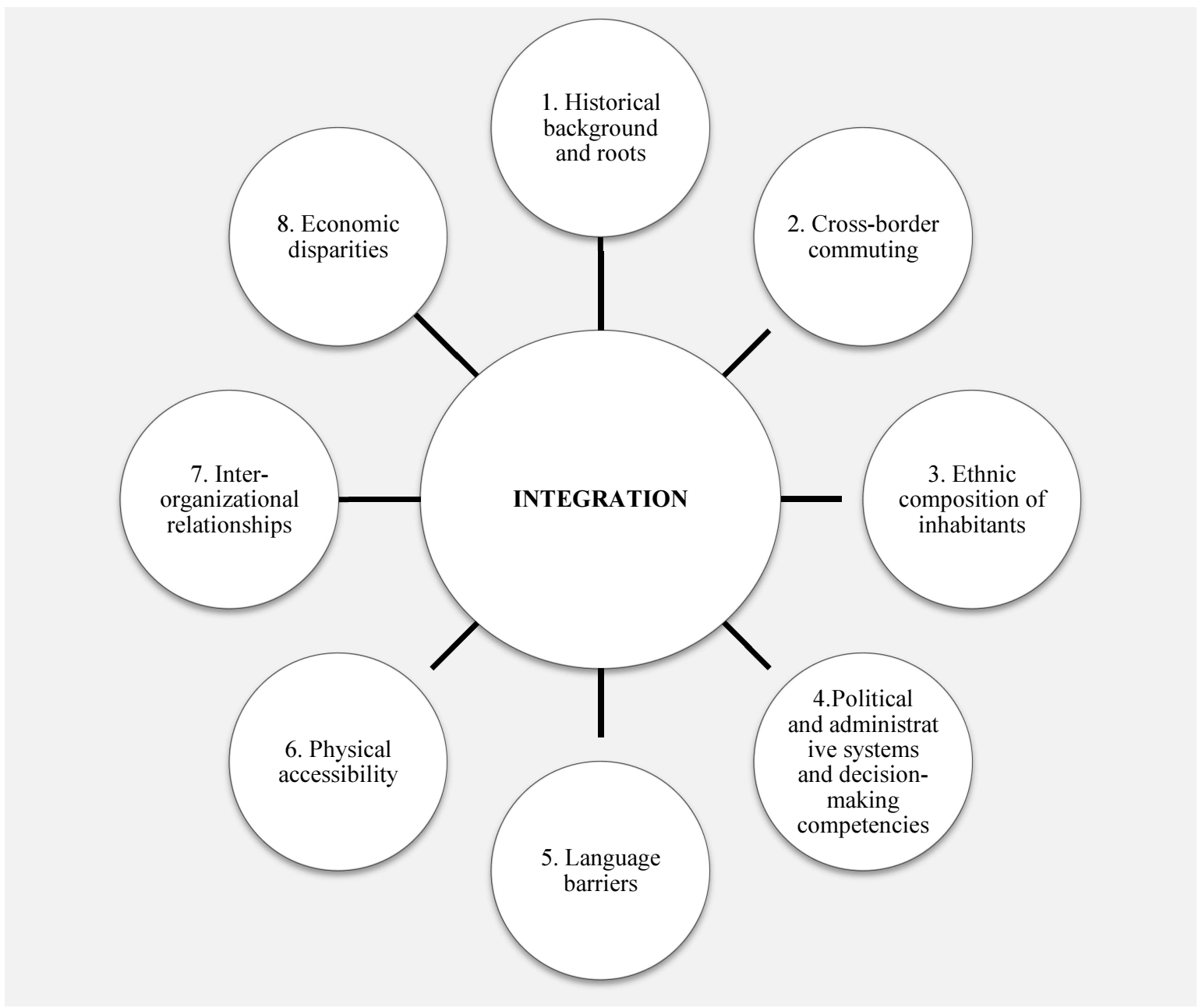

Source: Edited by Author 


\section{CONCLUSION}

The paper has examined the possible measurement methods of spatial integration at three (global, supranational and subnational) levels. Based on the reviewed scientific literature, the methodology of the measurement is significant distinct, not only from the aspect of several levels, but at same levels as well. The suggested integration factors can be developed and tested in the case of Central-Europe in the future, considering the specialities of this region. These factors can be divided into two different parts: hard and soft factors. The first one is relatively easy to measure, e.g. economic disparities, because several databases provide quantitative data, while soft factors e.g. common historical background and roots require in more cases literature review or qualitative research. These are suitable for the explanation of the results coming from hard factors. Presented researches for the integration processes of cross-border functional urban areas can provide an excellent basis to this investigation. The above mentioned Vienna-Bratislava relation is necessary to extend for the whole Centrope region and measure the integration in this multilateral system.

\section{Acknowledgement}

Supported by the official research project of Hungarian Academy of Sciences, Institute for Regional Studies Centre for Economic and Regional Studies, funded by Hungarian Scientific Research Fund www.otka.hu (ID: K 104801, project leader: Tamás Hardi).

\section{REFERENCES}

Baj, G. (2010). A területhasználat átalakulása. Hardi T.-Lados M.-Tóth K. (szerk). Magyarszlovák agglomeráció Pozsony környékén. MTA Regionális Kutatások Központja, Nyugat-magyarországi Tudományos Intézet; Fórum Kisebbségkutató Intézet. GyőrSomorja, 196-209.

Bartz, K. - Fuchs-Schündeln, N. (2012). The role of borders, languages, and currencies as obstacles to labor market integration. European Economic Review 56 (2012) 11481163.

Boe, D. - C. Grasland - Healy, A. et.a. (1999) Spatial integration. http://www.mcrit.com/SPESP/SPESP_REPORT/1.4.\%20Final\%20Report\%20(23-052000).pdf 33-46. [2014.10.24.]

Centrope (2010) Regional Development Report. Returning to Growth. http://www.centrope.com/repository/centrope/downloads_AT/Regional_Development_ Report_Broschuere_Englisch.pdf_[2014.12.08.]

Centrope (2014) Politics \& administration. http:/www.centrope.com/en/centroperegion/politics-and-administration [2014.12.08.]

Centrope (2015) At a European interface. http://www.centrope.com/en/centroperegion/centrope-at-a-glance [2015.02.24.]

Commendatore, P. - Kubin, I. - Petraglia, C - Sushko, I (2014). Regional integration, international liberalisation and the dynamics of industrial agglomeration. Journal of Economic Dynamics\&Control 48. 265-287.

Decoville, A. - Duran F. et.al. (2010) Spatial integration in European cross-border metropolitan regions: A comparative approach. Department of Geography, Centre for 
Population, Poverty and Public Policy Studies (CEPS/INSTEAD), PO Box 48, L-4501

Differdange, Luxembourg Working Paper No. 2010-40 December 2010. 1-19.

Endrődi-Kovács, V.(2010). Horvátország integrációérettsége. Délkelet-Európa - South-East Europe. International Relations Quarterly, 1 (1), 1-10.

Endrődi-Kovács, V. (2012). Szerbia integrációérettsége. Délkelet-Európa - South-East Europe. International Relations Quarterly, 3 (3), 1-16.

ESPON (2010). Metroborder. Cross-border Polycentric Metropolitan Regions. Targeted Analysis 2013/2/3 Final Report (31/12/2010) ESPON \& University of Luxembourg, 2010.

Halás, M. (2006). Theoretical preconditions versus the real existence of cross-border relations in the Slovak-Czech borderland. EUROPA. XXI. 15: 63-75.

Hardi, T.- Lampl, Zs. (2008). Határon átnyúló ingázás a szlovák-magyar határtérségben. Tér és Társadalom, 22. évf. 2008/3. 109-126.

Jagodič, D. (2010). Határon átívelő lakóhelyi mobilitás az Európai Unió belső határai mentén. Hardi T.-Lados M.-Tóth K. (szerk). Magyar-szlovák agglomeráció Pozsony környékén. MTA Regionális Kutatások Központja, Nyugat-magyarországi Tudományos Intézet; Fórum Kisebbségkutató Intézet. Győr-Somorja, 27-42.

Jennissen, R. (2011) Ethnic Migration in Central and Eastern Europe: Its Historical Background and Contemporary Flows. Volume 11, Issue 2, pp. 252-270

Kiss, É. (2005). Az Európai Unió a XXI. század elején. Akadémiai Kiadó, Budapest. 13.

Kocziszky, Gy. (2000). Regionális integrációk gazdaságtana. Bíbor Kiadó, Miskolc. 154.

KOF Swiss Economic Institute (2013). KOF Index of Globalization 2013.Slight Recovery of Economic Globalization.

http://globalization.kof.ethz.ch/media/filer_public/2013/03/25/press_release_2013_en.p df 1-7. [2014.03.04.]

Kovács, Z. (2001). Társadalomföldrajzi Kislexikon. Müszaki Könyvkiadó, Budapest. 75-76.

König, J. (2014) Measuring European Economic Integration - Dissertation zur Erlangung des wirtschaftswissenschaftlichen Doktorgrades der Wirtschaftswissenschaftlichen Fakultät der Georg-August-Universität Göttingen. 119. http://d-nb.info/1048469964/34 [2015.02.24.]

Kulcsár Zs. - Rostás S. (1989). (szerk.) Akadémiai Kislexikon I. Akadémiai Kiadó Budapest. Első kötet A-K. 822.

Lombaerde, P.D. - Langenhove, LV. (2005). Indicators of Regional Integration: Methodological Issues. IIIS Discussion Paper No. 64. 21.

METROLUX (2013) How can cross-border integration be measured? http://metrolux.ceps.lu/wa_cross_border_integration.cfm?m5=1 [2014.10.07.]

OECD (2012). List of urban areas by country. p.1. http://www.oecd.org/gov/regionalpolicy/all.pdf [2014.05.07.]

OECD (2013). "Defining regions and functional urban areas", in OECD Regions at a Glance 2013, OECD Publishing. http://www.oecdilibrary.org/docserver/download/0413091e.pdf?expires=1424621631\&id=id\&accname= guest\&checksum=F20DD4598536BB42EF8761E0EEAC6C7F 155. [2014.04.08.]

Operational Programme Objective European Territorial Co-operation Austria - Czech Republic 2007-2013

http://www.at-cz.eu/at-

cz/downloads/Programmdokumente/OP_AT_CZ_07_13_finale.pdf [2014.07.03.]

Palánkai, T. (2004). Economics of Enlarging European Union. Akadémiai Kiadó, Budapest.

Palánkai, T. (2010). Az integráció mérésének lehetőségei. Köz-gazdaság, (4), 47-72.

Prileszky, I. (2010). Közforgalmú közlekedés a határon átnyúló agglomerációban. Hardi T.Lados M.-Tóth K. (szerk). Magyar-szlovák agglomeráció Pozsony környékén. MTA 
Regionális Kutatások Központja, Nyugat-magyarországi Tudományos Intézet; Fórum Kisebbségkutató Intézet. Győr-Somorja, 162-177.

Rechnitzer, J. (1999). Az osztrák-magyar határ menti kapcsolatok múltja. In: Nárai MártaRechnitzer János (szerk.) Elválaszt és összeköt - a határ. Társadalmi-gazdasági változások az osztrák-magyar határ menti térségben. Pécs - Győr MTA Regionális Kutatások Központja. 73-129.

Schwiezer-Koch, M. (2013). Cross-border co-operation on regional innovation. http://essay.utwente.nl/64241/1/Bachelor\%20Thesis_Maike\%20SchwiezerKoch_s1003399.pdf [2015.01.21.]

URBACT, 2014 http://urbact.eu/en/projects/metropolitan-governance/egtc/our-project/ [2014.10.24.]

Uszkai, A. - Jóna, L. (2014). The automotive industry regional development challenges in Central and Eastern Europe. Rotschedl J, Čermáková K (ed.) Proceedings of the 13th International Academic Conference. Antibes, France, 15-18.09.2014. Prague: International Institute of Social and Economic Sciences (IISES), 628-645. 